\title{
The Effect of Firm Size on Predictability Future Cash Flows Using Earnings and Operating Cash Flows
}

\author{
NasrollahTakhtaei (Corresponding Author) \\ Assistant Professor, Accounting Department \\ Dezful Branch, Islamic Azad University, Dezful, Iran \\ E-mail: nasrollah_takhtaei@yahoo.com \\ Hassan Karimi \\ Accounting Department, Dezful Branch \\ Islamic Azad University, Dezful, Iran \\ E-mail: hasankarimi73@yahoo.com
}

Received: Nov. 2, 2016 Accepted: Dec. 1, $2016 \quad$ Published: June 1, 2017

doi:10.5296/ajfa.v9i1.10795 URL: https://doi.org/10.5296/ajfa.v9i1.10795

\begin{abstract}
The aim of this research is to investigate earnings relative ability, operating cash flow, and two traditional criteria of cash flow, that is, net earnings plus depreciation and operating working capital in predicting operating future cash flows. Further, the effect of firm size on the ability to predict these criteria is investigated in this research. The sample firms contain listed companies in Tehran Stock Exchange (TSE) over the period 2005-2009. The results show that net earnings relative to operating cash flows and its traditional criteria have greater ability to predict future cash flows in small firms whereas operating cash flows compared with other criteria are better predictors in big firms. Results indicate that the predictability of all models increases considerably when firm size increases.
\end{abstract}

Keywords: cash flow from operations, net earnings, small firms, large firms 


\section{Introduction}

During period between 1930 and 1960, many cases of corporation's merger and acquisition were occurred and a new form of financial transaction was generated. These issues caused new problems in the area of financial reporting which standard setters accomplished required actions to meet those concerns as soon as possible. This leads to a situation where managers could select accounting choices and procedures to mitigate for example earnings per share (EPS). The occurrence of numerous cases of managers' fraud was indicating managers' potential ability to misstate financial reporting due to different interpretations of generally accepted accounting principles (GAAP).Therefore, the ability of accrual-based financial reporting system as a main means of providing relevant and useful information for users was criticized (Birkett and Walker, 1971; Hendriksen, 1977). In order to satisfy limitations and inherent problems relating to accrual-based accounting, cash flow statement was extensively widespread as well as income statement and balance sheet. In the early 1970s, using voluntary reporting of funds statement by companies led accounting standard setters to require companies to prepare and publish funds statement by means of available accounting information within the income statement and balance sheet in a way that reflects financial resources flow. However, after 1970 and following a number of bankruptcies in some of the famous companies, usefulness of available information in cash flow statement for economic making-decision was strongly questioned. They argue that information of cash flows is better proxy for evaluating firms' financial flexibility. Lastly, a formal statement was issued by standard setters on which cash flow statement should be used instead of fund statement due to the strong support of cash flow statement by academician, financial managers, and organizations(Lee, 1971; Donleavy, 1994; Mulford and Comiskey, 2005).

\subsection{Usefulness of Accruals Accounting Data}

Regarding earnings as one of the key proxies of evaluating operations efficiency,Calabrese and Rafferty (2003) discuss that one of the advantages of using earnings is that operations evaluation process is not misstated by means of uncertain and changing cash flows. This is why financial transactions are recorded based on historical cost. Furthermore, using allocation, amortization, depreciation, and other existing processes in accruals basis allows companies to allocate assets cost during their useful life or during time in which interest result from those assets are acquired. Otherwise, if assets cost is regarded as expense in acquisition year, income statement report very small earnings or even result in loss for that given year and for the rest of the life years of those assets are not recognized any expenses in spite of the fact that those assets are being used to gain earnings which this does not seem rational and logical. Obviously, there are some arguments regarding data quality which is based on accruals accounting and specifically earnings as a measure of firm performance. This information provides situations involving manipulations using different accounting choices and mental factor and various estimates. Therefore, accounting information from accruals basis may be misstatement and calculated earnings also are changed to an unreliable proxy of firm performance(Bernard and Stober, 1989; Dechow, 1994). Accordingly, based-accruals earnings may not be useful significantly in predicting future cash flows notwithstanding these issues and problems and thus accounting information users apply cash flows rather than earnings in order to forecast 
future cash flows(Bierman, 1988; Sharma, 2001).

After 1980, U.S. and UK researchers and academician support the cash accounting concepts in order to change and adjust financial reporting systems. Cash accounting can avoid existing uncertain and unclear classifications and provide financial reports users with the more objective financial information and fundamental and key data as well(Lee, 1993). This is due to the fact that cash accounting does not contain concepts such as allocation and matching. In cash basis, transactions are recorded when either is paid or received cash related to. It is expected to be less manipulated cash basis relative to accruals basis(Ali, 1994; Sharma, 2001).Despite of the advantages of cash basis which supporters have put forward in the defense of this method, it has been criticized. Egginton (1984)and Rutherford (1982)assert that cash basis is not well protected from manipulation and discretionary classifications. Lee (1993)agrees with this problem and states that cash reporting system similar to other reporting systems has problems and states that individual judgments play an important role in reporting cash events. For instance, an individual judgment is necessitated when segments reporting are prepared. Classification of some of the cases such as operational cash flows or other cases related to cash also requires individual judgments. The succeeding problem is related to the disclosure of cash flows. In other words, cash flow statement is consisted of expressionssuch as cash flow from operations, expenditure, and cash equivalents which may not be easily understood by users.

\section{Background literature and hypotheses development}

Aghaei and Shakeri (2010) examine the ability of cash flow and accruals components of earnings in predicting firm's cash flow over the period 1382-1386. Based on their subject conceptual, they developed three regression models including; 1) earnings, 2) cash flow, and 3) cash flow and accruals components. They indicate that earnings, cash flow, and cash flow and accruals components have ability to predict future cash flow. Further, they also demonstrate that cash flow model and the model of cash flow and accruals components have better ability to predict relative to earnings model.

In another study carried out by Arab Mazar Yazdi and Safar Zadeh (2007), the earnings components in predicting future operational cash flows is investigated using a sample of 44 companies listed on Tehran Stock Exchange (TSE) over the period 1360-1384. They separate earnings into cash component and accruals component and they provide evidence indicating earnings components reflects different information concerning future cash flow. In addition, they separate accrual components into five components and they find that model explanatory power is improved by separating accrual components into more components.

Using a sample of 55 listed firms in Tehran Stock Exchange (TSE) during period 1374-1381, Gholam Ali Pour (2004) examines the ability of non-discretionary accruals in predicting earnings and future cash flows. They find that discretionary accruals have the ability of predicting future earnings but related R-squares is low whereas non-discretionary accruals do not have the ability of forecasting future cash flow. Furthermore, they indicate that the combination of non-discretionary accruals and cash flows in all years investigated have explanatory power but R-squares are relatively small. 
To predict cash flows, Modares and Diyanato Deilami (2003)considering four models with independent variables; 1) historical operating cash flows, 2) historical accounting earnings, 3) both historical operating cash flows and historical accounting earnings, and 4) operating cash flows, accounting earnings and items related to historical current assets and liabilities, investigate the ability of each models and accuracy of each model relative to other models. Their results show that predicting operating cash flows using historical operating cash flows is not possible whereas predicting operating cash flows using historical accounting earnings is significantly possible and hence superiority earnings relative to cash flows is confirmed in operating cash flows. They also indicate that both model of historical operating cash flows and historical accounting earnings, and model of operating cash flows, accounting earnings and items related to historical current assets and liabilities improve models considerably.

Raeiyat Kashani (1993) investigates the association between 1) accruals-based accounting earnings and different types of cash flows and 2) working capital from operation and operating cash flows during the period 1361-1368. The results indicate that earnings cannot show presents a clear interpretation as regard to cash flows and its related information.

In Australian context, Farshadfar, Ng, and Brimble (2008)explore the relative ability of earnings and cash flow and two traditional measures of cash flow (earnings plus depreciation plus amortization and operational working capital) in predicting future cash flow. They provide evidence that operating cash flow in comparison with earnings and calculated cash using traditional method has more power in forecasting future cash flow. Moreover, the ability of earnings and operating cash flow increase when firm size increases and superiority of operating cash flow over earnings is intensify as firm size increases in predicting operating cash flow.

Using a time series regression, Kim and Kross (2005)investigate the ability of current earnings in predicting succeeding operating cash flows during the period 1973-2000. They provide evidence that relation between earnings and succeeding operating cash flow is increased along with passing the time (with the exception of the some of the period, earnings in comparison to operating cash flow has more increased information contents).

Cheng and Hollie (2008)investigate the role of core and non-core cash flows in predicting future cash flows using Barth, Cram, and Nelson (2001)model. They demonstrate that core components relative to non-core components reflect different information as regard to future cash flows and separation cash components relative to Barth, Cram, and Nelson (2001) model improves predicting cash flow noticeably.

In another study conducted by Al-Attar and Hussain (2004)using Barth, Cram, and Nelson (2001)model, the accounting data ability including earnings, cash flows, and cash flows and accruals in predicting future cash flows for a sample of UK companies over period 1990-2000 is examined. Using panel data as well as ordinary least squares (OLS) regression; they provide evidence that separating earnings into cash and accruals improves predicting cash flows. Additionally, they indicate that historical cash flows in comparison with historical earnings have more ability to forecast cash flows and Historical cash flows in comparison to using cash flows and earnings accruals components contemporaneously are less powerful in predicting future cash flows. 
Using quarterly data for 30 companies over a period of 10 years, Jordan and Waldron (2001)investigate the ability of accrual-based accounting measures and cash-based accounting measures in order to predict future cash flows. The results indicate that all models have important predictability in predicting cash flows. Additionally, both R-squares and forecast errors percent show that predictability of NIDPR (net income before extraordinary items - plus depreciation and amortization) model is more than other models.

Krishnan and Largay Iii (2000) compare the direct and indirect methods of preparing cash flow statement in order to predict future cash flows during the period 1993-1998. Their sample includes all firms whose cash flow statement is prepared and reported in direct method. They compare two predictability models. The first one uses direct method cash flow information and the second one uses indirect method cash flow information in order to predict. They indicate that direct method cash flows prepare more accurate prediction than that of indirect method cash flows. Furthermore, they show that past cash flows of direct method are better predictors for future cash flows compared with accruals data and merely income.

Dechow, Kothari, and L. Watts (1998)develop a model of earnings, cash flows and accruals. They assume that sales create accounting cycle as to accounts receivable, accounts payable, and inventory. The model explains why current earnings compared with current operating cash flows are better predictors for future cash flows. They apply annual data for a sample of 667 firms over the period from 1963 to 1992. In their analysis, they define earnings as the earnings before extraordinary items and discontinued operations; cash flows from operations as the as operating income before depreciation minus interest minus taxes minus changes in noncash working capital; and also operating accruals as the earnings before extraordinary items and discontinued operations minus cash flow from operations. Using simple and multiple regressions, they demonstrate that current earnings are better predictors than that of current cash flows for future cash flows and difference in ability of earnings and historical cash flows for predicting future cash flows is subject to expected operating cash cycle of firms.

To provide an optimal model for predicting future cash flow, Lorek and Willinger (1996) use seasonal data rather than annual data. They developed a multivariate time series model using operating income, operating cash flows, and current assets and liabilities. Their results indicate that multivariate time series model predict operating cash flows in a better way. According to findings, the use of accruals has better ability for predicting cash flows than cash flows which is consistent with the claim of Financial Accounting Standards Board (FASB).

McBeth (1993) examines the ability of cash flows and earnings in order to predict the future cash flows. He directly obtains cash flow from operations from statement of cash flows and earnings from income statement of the companies. He finds that neither past earnings nor cash flows from operations could be suitable predictor for future cash flows.

Percy and Stokes (1992) replicate the analysis conducted by Bowen, Burgstahler, and Daley (1986). They employ two measures of cash flows. The first measure which is traditional is composed of net income plus depreciation and amortization plus working capital from operations and the second measure is comprised of working capital from operations plus extra adjustments from changes in current non-cash and current liabilities which was more modified. 
In order to investigate the relationship between cash flows and earnings, they apply data from a sample of 99 Australian firms in23 industry groups over the period from 1974 to 1985 . Their findings were in line with the findings of the Bowen, Burgstahler, and Daley (1986). This means that traditional measure of cash flows (first measure) provide more accurate prediction for predicting cash flows for one or two future years compared with the measure of modified cash flows (second measure).

Bowen, Burgstahler, and Daley (1986) investigate the association between earnings and different measures of cash flows. Additionally, they compare the predictability of earnings versus cash flows in order to predict future cash flows. Using financial statements data of a sample of 324 firms during period from 1971 to 1981, they demonstrate that accruals-based earnings are highly related to traditional measures of cash flows (working capital from operations and earnings before extraordinary items and discontinued operations plus depreciation). However, they report a low association between other measures such as cash flow from operations, cash flow after investing activities and before financing activities, finally changes in cash during the financial period.

According to the literature, this study developed four hypotheses as follows:

H1: operational cash flows have ability to predict future cash flows.

H2: current earnings have ability to predict future cash flows.

H3: current earnings plus depreciation have ability to predict future cash flows.

H4: operational working capital has ability to predict future cash flows.

\section{Research Design}

The main purpose of this study is to provide evidence with respect to relative usefulness of accruals-based earnings cash flow from operations (reported in cash flow statement) in predicting future cash flow. Therefore, to investigate the predictive ability of measures of earnings and cash flow in predicting future cash flows, this study estimates the following model explaining cash flow from operations in year $t\left(C F O_{i, t}\right)$, incorporating the four primary variables of net earnings before tax and after extraordinary items in year $t-1\left(E A R N S_{i, t-1}\right)$, net earnings before extraordinary items plus depreciation and amortization expense in year $t-$ $1\left(N E B E P D A_{i, t-1}\right)$, working capital from operations in year $t-1\left(W C F O_{i, t-1}\right)$, cash flow from operations in year $t-1\left(C F O_{i, t-1}\right)$, initially using OLS regression analysis. This study investigates to what extent the association of earnings and cash flow from operations with future cash flow from operations is influenced by firm size.

\subsection{Sample Selection Process}

The sampleconsists of 94 Iranian companies, representing almost all non-financial firms listed on the Tehran Stock Exchange (TSE) for the period 2005-2009. However, the sample selection process is based on the following criteria: (i) the companies should be listed on Tehran stock exchange during the period from 2005 to 2009 ,(ii) in order to compare data, the end of financial year $\left(20^{\text {th }}\right.$ March $)$ of the selected companies should be the same and the 
companies should not change their financial year during the covered period, and (iii) financial companies such as banks, investment companies are excluded because their balance sheet data are not comparable with those of nonfinancial firms. Additionally, in order to test the research hypotheses in two groups of companies, this study decomposes the full sample into large and small companies based on firms' shares market value. The decomposition has also been done based on median of firms' shares market value where companies with shares market value equal or larger than median are regarded as large companies and small companies otherwise. Finally, the result of the decomposition indicates 45 large and 49 small companies.

\subsection{Variables Definition}

3.2.1 Cash flow from operations (CFO): operating activities is composed of main activities of business entity's revenue productive. These operations require production and sell goods and render service and expenses, revenues relating to those are considered in determination of operational income or loss in income statement. Cash flows from operational activities are basically consisting cash inflows and outflows with regard to mentioned operations that it is the latest figure reported in the section of cash flows from operating activities in cash flow statement.

3.2.2 Earnings (EARNS): net earnings after tax but before extraordinary items (reported in income statement)

3.2.3 Net earnings before extraordinary items plus depreciation and amortization expense (NEBEPDA): one of the traditional measures is cash flow that is calculated with adding period depreciation expense (tangible and intangible assets) to net earnings before extraordinary items.

3.2.4 Working capital from operations (WCFO): working capital from operations is the second traditional measure of cash flow that is calculated as following:

Operational cash flows $=$ change in current assets with the exception of cash - change in current liabilities

\subsection{2eeModel Specifications}

To test the hypotheses with respect to impact of net earnings before tax and after extraordinary items in year $t-1\left(E A R N S_{i, t-1}\right)$, net earnings before extraordinary items plus depreciation and amortization expense in year $t-1\left(N E B E P D A_{i, t-1}\right)$, working capital from operations in year $t-1\left(W C F O_{i, t-1}\right)$, cash flow from operations in year $t-1\left(C F O_{i, t-1}\right)$ on cash flow from operations in year $t\left(C F O_{i, t}\right)$, the following multivariate OLS regression model is established:

$$
C F O_{i, t}=\beta_{0}+\beta_{1} E_{A R N S_{i, t-1}}+\beta_{2} N E B E P D A_{i, t-1}+\beta_{3} W_{C F O_{i, t-1}}+\beta_{4} C F O_{i, t-1}+\varepsilon_{i, t}
$$

Where; 
$C F O_{i, t}=\quad$ Cash flow from operations in year $t$

$E A R N S_{i, t-1}=$ Net earnings before tax and after extraordinary items in year $t-1$;

$N E B E P D A_{i, t-1}=$ Net earnings before extraordinary items plus depreciation and amortization expense in year $t-1$;NEBEPDA

$W C F O_{i, t-1}=\quad$ Working capital from operations in year $t-1$;

$C F O_{i, t-1}=$ Cash flow from operations in year $t-1$;

$\varepsilon_{i, t}=\quad$ Residuals;

\section{Empirical Results and Analysis}

Table 4.1 indicates OLS regression of cash flow from operations in year $t\left(C F O_{i, t}\right)$ onnet earnings before tax and after extraordinary items in year $t-1\left(E A R N S_{i, t-1}\right)$, net earnings before extraordinary items plus depreciation and amortization expense in year $t-1$ $\left(N E B E P D A_{i, t-1}\right)$, working capital from operations in year $t-1\left(W C F O_{i, t-1}\right)$, cash flow from operations in year $t-1\left(C F O_{i, t-1}\right)$ in large companies.

Table 4.1 shows that in MODEL1, cash flow from operations in year $t-1\left(C F O_{i, t-1}\right)$ $(\beta=0.8483, p<0.01)$ is positively and significantly associated with cash flow from operations in year $t\left(C F O_{i, t}\right) . F$-statistics is significant $(p<0.01)$ and $R^{2}$ is $33.80 \%$. Durbin-Watson test is 1.98 , indicating no autocorrelation in residuals. Therefore, the results support the first hypothesis for large companies. In MODEL2, net earnings before tax and after extraordinary items in year $t-1\left(E A R N S_{i, t-1}\right)(\beta=0.5494, p<0.01)$ is positively and significantly associated with cash flow from operations in year $t\left(C F O_{i, t}\right)$. F-statistics is significant $(p<0.01)$ and $R^{2}$ is $31.58 \%$. Durbin-Watson test is 2.09 , indicating no autocorrelation in residuals. Therefore, the results support the second hypothesis for large companies. In MODEL3, net earnings before extraordinary items plus depreciation and amortization expense in year $t-1\left(N E B E P D A_{i, t-1}\right)$ ( $\beta=0.5674, p<0.01)$ is positively and significantly associated with cash flow from operations in year $t\left(C F O_{i, t}\right)$. F-statistics is significant $(p<0.01)$ and $R^{2}$ is $32.11 \%$. Durbin-Watson test is 2.08 , indicating no autocorrelation in residuals. Therefore, the results support the third hypothesis for large companies. In MODEL4, working capital from operations in year $t-1$ $\left(W C F O_{i, t-1}\right)(\beta=0.2515, p<0.01)$ is positively and significantly associated with cash flow from operations in year $t\left(C F O_{i, t}\right)$. F-statistics is significant $(p<0.01)$ and $R^{2}$ is $25.38 \%$. Durbin-Watson test is 2.11 , indicating no autocorrelation in residuals. Therefore, the results support the fourth hypothesis for large companies.

In order to use multiple regressions in addition to simple regression, we have to check the potential multicollinearity problem for independent variables using variance inflation factor (VIF) test. In terms of VIF test, the results indicate that variance inflation factor (VIF) for variables such as $C F O_{i, t-1}, E A R N S_{i, t-1}, N E B E P D A_{i, t-1}, W C F O_{i, t-1}$, is 2.482, 27.138, 27.636, and 2.512 respectively. The multicollinearity is likely to be a substantive issue in this study, since the VIF for variables such as net earnings before tax and after extraordinary items in year $t-$ $1\left(E A R N S_{i, t-1}\right)$, net earnings before extraordinary items plus depreciation and amortization expense in year $t-1\left(N E B E P D A_{i, t-1}\right)$ is larger than 10 . Therefore, in addition to the simple regression for each hypothesis and to remove the molticollinearity, we run two multiple 
regression, one (MODEL5) with variables such as $C F O_{i, t-1}, N E B E P D A_{i, t-1}$, and $W C F O_{i, t-1}$, the other (MODEL6) with $C F O_{i, t-1}, E A R N S_{i, t-1}$, and $W C F O_{i, t-1}$.

In MODEL5, cash flow from operations in year $t-1\left(C F O_{i, t-1}\right)(\beta=0.4970, p<0.01)$ and net earnings before extraordinary items plus depreciation and amortization expense in year $t-1$ $\left(N E B E P D A_{i, t-1}\right)(\beta=0.4153, p<0.01)$ are positively and significantly associated with cash flow from operations in year $t\left(C F O_{i, t}\right)$. However, working capital from operations in year $t-1$ $\left(W C F O_{i, t-1}\right)(\beta=-0.0201, p>0.05)$ is not significantly associated with cash flow from operations in year $t\left(C F O_{i, t}\right)$. F-statistics is significant $(p<0.01)$ and adjusted $R^{2}$ is $38.49 \%$. Durbin-Watson test is 2.17, indicating no autocorrelation in residuals. In MODEL6, cash flow from operations in year $t-1\left(C F O_{i, t-1}\right)(\beta=0.5054, p<0.01)$ and net earnings before tax and after extraordinary items in year $t-1\left(E A R N S_{i, t-1}\right)(\beta=0.5494, p<0.01)$ are positively and significantly associated with cash flow from operations in year $t\left(C F O_{i, t}\right)$. However, working capital from operations in year $t-1\left(W C F O_{i, t-1}\right)(\beta=-0.0122, p>0.05)$ is not significantly associated with cash flow from operations in year $t\left(C F O_{i, t}\right) . F$-statistics is significant $(p<0.01)$ and adjusted $R^{2}$ is $38.05 \%$. Durbin-Watson test is 2.16 , indicating no autocorrelation in residuals.

Table 4.1. Multiple regression results for large companies

\begin{tabular}{|c|c|c|c|c|c|c|}
\hline Variables & MODEL1 & MODEL2 & MODEL3 & MODEL4 & MODEL5 & MODEL6 \\
\hline \multirow[t]{2}{*}{$C F O_{i, t-1}$} & $0.8483 * * *$ & & & & $0.4970 * * *$ & $0.5054 * * *$ \\
\hline & $(0.0000)$ & & & & $(0.0002)$ & $(0.0001)$ \\
\hline \multirow[t]{2}{*}{$E_{A R N S_{i, t-1}}$} & & $0.5494 * * *$ & & & & $0.3994 * * *$ \\
\hline & & $(0.0000)$ & & & & $(0.0050)$ \\
\hline \multirow[t]{2}{*}{$N E B E P D A_{i, t-1}$} & & & $0.5674 * * *$ & & $0.4153 * * *$ & \\
\hline & & & $(0.0000)$ & & $(0.0041)$ & \\
\hline \multirow[t]{2}{*}{$W C F O_{i, t-1}$} & & & & $0.2515 * * *$ & -0.0201 & -0.0122 \\
\hline & & & & $(0.0000)$ & $(0.8276)$ & $(0.8944)$ \\
\hline \multirow[t]{2}{*}{ Constant } & $0.0844 * * *$ & $0.1175 * * *$ & $0.1024 * * *$ & $0.2007 * * *$ & $0.0469 * *$ & $0.0558 * *$ \\
\hline & $(0.0000)$ & $(0.0003)$ & $(0.0029)$ & $(0.0000)$ & $(0.0467)$ & $(0.0119)$ \\
\hline Observations & 225 & 225 & 225 & 225 & 225 & 225 \\
\hline$D-W$ Statistics & 1.98 & 2.09 & 2.08 & 2.11 & 2.17 & 2.16 \\
\hline$R^{2}$ & $33.80 \%$ & $31.58 \%$ & $32.11 \%$ & $25.38 \%$ & $39.32 \%$ & $38.88 \%$ \\
\hline Adj. $R^{2}$ & $33.21 \%$ & $30.96 \%$ & $31.49 \%$ & $24.71 \%$ & $38.49 \%$ & $38.05 \%$ \\
\hline$F$-statistics & $56.4354 * * *$ & $51.0077 * * *$ & $52.2531 * * *$ & $37.5918^{* * *}$ & $47.7290 * * *$ & $46.8607 * * *$ \\
\hline
\end{tabular}

Note: $p$-values in parentheses, *,**,*** denote two-tailed significance at the $10 \%, 5 \%, 1 \%$ level, respectively.

Variables definition: $C F O_{i, t-1}=$ cash flow from operations in year $t-1 ; E A R N S_{i, t-1}=$ net earnings before tax and after extraordinary items in year $t-1 ; N E B E P D A_{i, t-1}=$ net earnings before extraordinary items plus depreciation and amortization expense in year $t-1 ; W C F O_{i, t-1}=$ working capital from operations in year $t$ $-1$ 
Table 4.2 indicates OLS regression of cash flow from operations in year $t\left(\mathrm{CFO}_{i, t}\right)$ oncash flow from operations in year $t-1\left(C F O_{i, t-1}\right)$, net earnings before tax and after extraordinary items in year $t-1\left(E A R N S_{i, t-1}\right)$, net earnings before extraordinary items plus depreciation and amortization expense in year $t-1\left(N E B E P D A_{i, t-1}\right)$, working capital from operations in year $t$

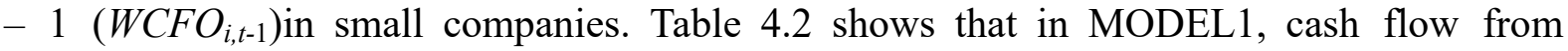
operations in year $t-1\left(C F O_{i, t-1}\right)(\beta=0.3617, p<0.01)$ is positively and significantly associated with cash flow from operations in year $t\left(C F O_{i, t}\right)$. F-statistics is significant $(p<0.01)$ and $R^{2}$ is $11.08 \%$. Durbin-Watson test is 2.10 , indicating no autocorrelation in residuals. Therefore, the results support the first hypothesis for small companies. In MODEL2, net earnings before tax and after extraordinary items in year $t-1\left(E A R N S_{i, t-1}\right)(\beta=0.5548, p<0.01)$ is positively and significantly associated with cash flow from operations in year $t\left(C F O_{i, t}\right)$. F-statistics is significant $(p<0.01)$ and $R^{2}$ is $17.09 \%$. Durbin-Watson test is 1.82 , indicating no autocorrelation in residuals. Therefore, the results support the second hypothesis for small companies. In MODEL3, net earnings before extraordinary items plus depreciation and amortization expense in year $t-1\left(N E B E P D A_{i, t-1}\right)(\beta=0.5478, p<0.01)$ is positively and significantly associated with cash flow from operations in year $t\left(C F O_{i, t}\right)$. F-statistics is significant $(p<0.01)$ and $R^{2}$ is $17.14 \%$. Durbin-Watson test is 1.83 , indicating no autocorrelation in residuals. Therefore, the results support the third hypothesis for small companies. In MODEL4, working capital from operations in year $t-1\left(W C F O_{i, t-1}\right)(\beta=0.2865$, $p<0.01)$ is positively and significantly associated with cash flow from operations in year $t$ $\left(C F O_{i, t}\right) . F$-statistics is significant $(p<0.01)$ and $R^{2}$ is $12.97 \%$. Durbin-Watson test is 2.00 , indicating no autocorrelation in residuals. Therefore, the results support the fourth hypothesis for large companies.

In MODEL5, net earnings before extraordinary items plus depreciation and amortization expense in year $t-1\left(N E B E P D A_{i, t-1}\right)(\beta=0.4092, p<0.01)$ are positively and significantly associated with cash flow from operations in year $t\left(C F O_{i, t}\right)$. However, cash flow from operations in year $t-1\left(C F O_{i, t-1}\right)(\beta=0.1079, p>0.05)$ and working capital from operations in year $t-1\left(W C F O_{i, t-1}\right)(\beta=0.1070, p>0.05)$ is not significantly associated with cash flow from operations in year $t\left(C F O_{i, t}\right)$. F-statistics is significant $(p<0.01)$ and adjusted $R^{2}$ is $20.22 \%$. Durbin-Watson test is 2.06, indicating no autocorrelation in residuals. In MODEL6, net earnings before tax and after extraordinary items in year $t-1\left(E A R N S_{i, t-1}\right)(\beta=0.4131, p<0.01)$ are positively and significantly associated with cash flow from operations in year $t\left(C F O_{i, t}\right)$. However, cash flow from operations in year $t-1\left(C F O_{i, t-1}\right)(\beta=0.1150, p>0.05)$ and working capital from operations in year $t-1\left(W C F O_{i, t-1}\right)(\beta=0.1074, p>0.05)$ is not significantly associated with cash flow from operations in year $t\left(C F O_{i, t}\right)$. F-statistics is significant $(p<0.01)$ and adjusted $R^{2}$ is $20.13 \%$. Durbin-Watson test is 2.07 , indicating no autocorrelation in residuals. 
Table 4.2. Multiple regression results for small companies

\begin{tabular}{|c|c|c|c|c|c|c|}
\hline Variables & MODEL1 & MODEL2 & MODEL3 & MODEL4 & MODEL5 & MODEL6 \\
\hline$C F O_{i, t-1}$ & $\begin{array}{l}0.3617 * * * \\
(0.0009)\end{array}$ & & & & $\begin{array}{l}0.1079 \\
(0.4179)\end{array}$ & $\begin{array}{l}0.1150 \\
(0.3810)\end{array}$ \\
\hline$E A R N S_{i, t-1}$ & & $\begin{array}{l}0.5548 * * * \\
(0.0000)\end{array}$ & & & & $\begin{array}{l}0.4131^{* * *} \\
(0.0012)\end{array}$ \\
\hline$N E B E P D A_{i, t-1}$ & & & $\begin{array}{l}0.5478 * * * \\
(0.0000)\end{array}$ & & $\begin{array}{l}0.4092 * * * \\
(0.0010)\end{array}$ & \\
\hline$W C F O_{i, t-1}$ & & & & $\begin{array}{l}0.2865^{* * *} \\
(0.0000)\end{array}$ & $\begin{array}{l}0.1070 \\
(0.1517)\end{array}$ & $\begin{array}{l}0.1074 \\
(0.1474)\end{array}$ \\
\hline Constant & $\begin{array}{l}0.0804 * * * \\
(0.0000)\end{array}$ & $\begin{array}{l}0.0559 * * * \\
(0.0000)\end{array}$ & $\begin{array}{l}0.0424^{* * *} \\
(0.0017)\end{array}$ & $\begin{array}{l}0.0104 * * * \\
(0.0000)\end{array}$ & $\begin{array}{l}0.0382 * * * \\
(0.0041)\end{array}$ & $\begin{array}{l}0.0477 * * \\
(0.0003)\end{array}$ \\
\hline Observations & 245 & 245 & 245 & 245 & 245 & 245 \\
\hline$D-W$ Statistics & 2.10 & 1.82 & 1.83 & 2.00 & 2.06 & 2.07 \\
\hline$R^{2}$ & $11.08 \%$ & $17.09 \%$ & $17.14 \%$ & $12.97 \%$ & $21.20 \%$ & $21.11 \%$ \\
\hline Adj. $R^{2}$ & $10.72 \%$ & $16.75 \%$ & $13.47 \%$ & $12.61 \%$ & $20.22 \%$ & $20.13 \%$ \\
\hline F-statistics & $30.2884^{* * *}$ & $50.0797^{* * *}$ & $51.4755^{* * *}$ & $36.2212 * * *$ & $21.6187^{* * *}$ & $21.4990^{* * *}$ \\
\hline
\end{tabular}

Note: $p$-values in parentheses, $*, * *, * * *$ denote two-tailed significance at the $10 \%, 5 \%, 1 \%$ level, respectively.

Variables definition: $C F O_{i, t-1}=$ cash flow from operations in year $t-1 ; E A R N S_{i, t-1}=$ net earnings before tax and after extraordinary items in year $t-1 ; N E B E P D A_{i, t-1}=$ net earnings before extraordinary items plus depreciation and amortization expense in year $t-1 ; W C F O_{i, t-1}=$ working capital from operations in year $t$ $-1$

\section{Conclusion and Discussion}

According to findings, the results of hypotheses test at the level of large companies are relatively different from that of small companies. As it is shown in table 2.5, net earnings before extraordinary items plus depreciation and amortization expense in year $t-1$ $\left(N E B E P D A_{i, t-1}\right)$ rather than net earnings before tax and after extraordinary items in year $t-1$ $\left(E A R N S_{i, t-1}\right)$ is the best predictor with a little different. Net earnings before tax and after extraordinary items in year $t-1\left(E A R N S_{i, t-1}\right)$, working capital from operations in year $t-1$ $\left(W C F O_{i, t-1}\right)$ and cash flow from operations in year $t-1\left(C F O_{i, t-1}\right)$ are other best predictors respectively after net earnings before extraordinary items plus depreciation and amortization expense in year $t-1\left(N E B E P D A_{i, t-1}\right)$. With regard to the multiple regression models(models 5 and 6) in small companies, although the coefficients of variables in multiple regression models5 and 6 are significant and coefficients of variables such as cash flow from operations in year $t-1\left(C F O_{i, t-1}\right)$ and working capital from operations in year $t-1\left(W C F O_{i, t-1}\right)$ are not significant in both model 5 and model 6 , the multiple regression models may not be used to predict future cash flows. In large companies, cash flow from operations in year $t-1\left(C F O_{i, t-1}\right)$ in relation to net earnings before tax and after extraordinary items in year $t-1\left(E A R N S_{i, t-1}\right)$ is better predictor for predicting future cash flow from operations, whereas in small companies 
net earnings before tax and after extraordinary items in year $t-1\left(E A R N S_{i, t-1}\right)$ is better predictor than cash flow from operations in year $t-1\left(C F O_{i, t-1}\right)$. These results are consistent with the findings of Farshadfar, $\mathrm{Ng}$, and Brimble (2008), Al-Attar and Hussain (2004), and Quirin et al. (1999).The reason of this finding may be explained by political costs hypothesis. The political costs hypothesis has been raised in positive accounting theories by politician and regulators due to the use of earnings numbers. The report of lower earnings would probably leads to reduction of any actions against these companies and would increase the probability of governmental subsidies receiving, while increases and high positive percentages would attract the attention of national media and authorities as the proxy for crisis and monopoly(Khosh Tinat and Nowrouzbeigi, 2008). Therefore, it can be said that due to the manipulating earnings numbers in large companies, reliability of cash flow from operations in year $t-1\left(C F O_{i, t-1}\right)$ is higher which can be used as a better measure for predicting future cash flows. This is a significant difference that it can be seen between the results of large and small companies.Moreover, it can be stated that in large companies unlike small companies, using cash flow from operations in year $t-1\left(C F O_{i, t-1}\right)$, net earnings before extraordinary items plus depreciation and amortization expense in year $t-1\left(N E B E P D A_{i, t-1}\right)$, and working capital from operations in year $t-1\left(W C F O_{i, t-1}\right)$ (MODEL5) simultaneously, and also the use of cash flow from operations in year $t-1\left(C F O_{i, t-1}\right)$, net earnings before tax and after extraordinary items in year $t-1\left(E A R N S_{i, t-1}\right)$, and working capital from operations in year $t-1\left(W C F O_{i, t-1}\right)$ simultaneously (MODEL6), in relation to use of only each variable improve the prediction model to a great extent. Additionally, as the results indicate, the predictive ability of all models for large companies is larger than that of all models for small companies. In other words, as the firm size increases, the predictive ability increases for all models. Therefore, it can be said that firm size plays an important role in predictability future cash flows using aforementioned models.

\section{References}

Aghaei, M., \& Shakeri, A. . (2010). Application Cash Flow Ratios, Cash Flows and Accrual Accounting in Predicting Future Operating Cash Flow in Listed Companies of Tehran Stock Exchange. Journal of Financial Accounting, 2(5), 1-16.

Al-Attar, Ali, \& Hussain, Simon. (2004). Corporate Data and Future Cash Flows. Journal of Business Finance \& Accounting, 31(7-8), 861-903. https://doi.org/10.1111/j.0306-686X.2004.00560.x

Ali, Ashiq. (1994). The Incremental Information Content of Earnings, Working Capital from Operations, and Cash Flows. Journal of Accounting Research, 32(1), 61-74. https://doi.org/10.2307/2491387

Arab Mazar Yazdi, Mohammad, \& Safar Zadeh, Mohammad Hossein. (2007). Earnings Components Split and Predicting Future Cash Flows from Operations. Accounting and Auditing Review, 14(3), 111-138. 
Barth, Mary E., Cram, Donald P., \& Nelson, Karen K. (2001). Accruals and the Prediction of Future Cash Flows. The Accounting Review, 76(1), 27-58. https://doi.org/10.2308/accr.2001.76.1.27

Bernard, Victor L. \&, Stober, Thomas L. (1989). The Nature and Amount of Information in Cash Flows and Accruals. The Accounting Review, 64(4),624-652.

Bierman, Harold. (1988). Extending the Usefulness of Accrual Accounting. Accounting Horizons, 2(3), 10-14.

Birkett, W. P. \&, Walker, R. G. (1971). Response of the Australian Accounting Profession to Company Failure in the 1960s1. Abacus, 7(2), 97-136. https://doi.org/10.1111/j.1467-6281.1971.tb00400.x

Bowen, Robert M., Burgstahler, David, \& Daley, Lane A. (1986). Evidence on the Relationships between Earnings and Various Measures of Cash Flow. The Accounting Review, 61(4), 713-725.

Calabrese, J., \& Rafferty, B.A. (2003). EBITDA: What YourBorrower is Measuring and How it Affect Cash. Commercial Lending Review and Finance, 18(3), 41-44.

Cheng, CS Agnes, \& Hollie, Dana. (2008). Do core and non-core cash flows from operations persist differentially in predicting future cash flows? Review ofQuantitative Finance and Accounting, 31(1), 29-53.

Dechow, Patricia M. (1994). Accounting earnings and cash flows as measures of firm performance: The role of accounting accruals. Journal of Accounting and Economics, 18(1), 3-42. https://doi.org/10.1016/0165-4101(94)90016-7

Dechow, Patricia M., Kothari, S. P., \& L. Watts, Ross. (1998). The relation between earnings and cash flows. Journal of Accounting and Economics, 25(2), 133-168. https://doi.org/10.1016/S0165-4101(98)00020-2

Donleavy, G. D. (1994). Cash Flow Accounting: International Uses and Abuses. London: Routhledge.

Egginton, D. A. (1984). In Defence of Profit Measurement: Some Limitations of Cash Flow and Value Added as Performance Measures for External Reporting. Accounting and Business Research, 14(54), 99-111. https://doi.org/10.1080/00014788.1984.9729197

Farshadfar, Shadi, Ng, Chew, \& Brimble, Mark. (2008). The relative ability of earnings and cash flow data in forecasting future cash flows: Some Australian evidence. Pacific Accounting Review, 20(3), 254-268. https://doi.org/10.1108/01140580810920236

Gholam Ali Pour, Reza. (2004). The Ability of Non-Discretionary in Predicting Earnings and Future Cash Flows. (M.A .Dissertation), University of Shahid Beheshti, Tehran .

Hendriksen, ES. (1977). Accounting Theory (5th ed.). Homewood, Illinois: Richard D. Irwin. 
Jordan, Charles E., \& Waldron, Marilyn A. (2001). Predicting Cash Flow from Operations: Evidence on the Comparative Abilities for A Continuum of Measures. Journal of Applied Business Research (JABR), 17(3), 751-780.

Khosh Tinat, Mohsen, \& Nowrouzbeigi, Ebrahim. (2008). Accounting Political Process. Accountant Magazine (Hesabdar's Monthly), 22(187).

Kim, Myungsun, \& Kross, William. (2005). The Ability of Earnings to Predict Future Operating Cash Flows Has Been Increasing-Not Decreasing. Journal of Accounting Research, 43(5), 753-780. https://doi.org/10.1111/j.1475-679X.2005.00189.x

Krishnan, Gopal V., \& Largay Iii, James A. (2000). The Predictive Abilityof Direct Method Cash Flow Information. Journal of Business Finance \& Accounting, 27(1-2), 215-245. https://doi.org/10.1111/1468-5957.00311

Lee, T. (1971). Goodwill: An Example of Will-o'the-Wisp Accounting. Accounting and Business Research, 318-328. Autumn. https://doi.org/10.1080/00014788.1971.9728985

Lee, Thomas A. (1993). Cash FlowReporting: A Recent History of An Accounting Practice. New York: Garland Publishing.

Lorek, Kenneth S., \& Willinger, G. Lee. (1996). A Multivariate Time-Series Prediction Model for Cash-Flow Data. The Accounting Review, 71(1), 81-102.

McBeth, K. (1993). Forecasting Operating Cash Flow: Evidence on the Comparative Predictive Abilities of Net Income and Operating Cash Flow from Actual Cash Flow Data. Mid-Atlantic Journal of Business, 29(2), 173-187.

Modares, Ahmad, \& Diyanato Deilami, Zahra. (2003). TheReview of Application Multivariate Time Series Model in Predicting Cash Flow from Operations. Accounting and Auditing Review, 34, 77-110.

Mulford, Charles W. \& Comiskey, Eugene E. (2005). Creative Cash Flow Reporting: Uncovering Sustainable Financial Performance. New Jersey: John Wiley \& Sons.

Percy, Majella, \& Stokes, Donald J. (1992). Further Evidence on Empirical Relationships between Earnings and Cash Flows. Accounting \& Finance, 32(1), 27-49. https://doi.org/10.1111/j.1467-629X.1992.tb00175.x

Quirin, Jeffrey J., O'Bryan, David, Wilcox, William E., \& Berry, Kevin T. (1999). Forecasting Cash Flow from Operations: Additional Evidence. Mid-Atlantic Journal of Business, 35, 135-142.

Raeiyat Kashani, Mohammad. (1993). Evidence on the Association between Accounting Earnings Measureing by Cash Flow. (M.A .Dissertation), University of Tarbiyat Modares, Tehran.

Rutherford, B. A. (1982). The Interpretation of Cash Flow Reports and the Other Allocation Problem. Abacus, 18(1), 40-49. https://doi.org/10.1111/j.1467-6281.1982.tb00019.x 
Sharma, Divesh S. (2001). The role of cash flow information in predictingcorporate failure: the state of the literature. Managerial Finance, 27(4), 3-28. https://doi.org/10.1108/03074350110767114 